\title{
Self-Efficacy of English Education Students in a Private University in Makassar: A Comparison across Batches ${ }^{1}$
}

\author{
Awaluddin Syamsu, Muhammad Yunus, and Rizkariani Sulaiman \\ Universitas Muslim Indonesia \\ Email: awaluddin.syamsu@umi.ac.id
}

\begin{abstract}
Teacher's self-efficacy has been linked with their positive performance and it starts developing in their study time at university. Therefore, curriculum at university plays an important role to create a gradual increase of the student teacher's self-efficacy. So the students with higher academic year should have a better level of self-efficacy. This research aimed at finding out the efficacy for student engagement, instructional strategy, and classroom management of the English Education students in four different years of intake. The study was conducted in one of the reputable private Universities in Makassar, Indonesia. A Short Teacher Sense of Efficacy Scale (Tschannen-Moran \& Woolfolk Hoy, 2001) was employed as questionnaire tool to collect data. The data obtained from 122 students was computed using SPSS with non-parametric test. The result indicated that the lowest three aspects of self-efficacy level were found in the last two years of their study whereas the highest self-efficacy level was found in the first two years students. This research suggests the importance of modifying a curriculum which can assure that the selfefficacy increase during their academic study.
\end{abstract}

KEYWORDS: Self-efficacy, Student teachers, English education, Teacher Sense of Self-Efficacy

\section{INTRODUCTION}

Self-efficacy is a term coined by Albert Bandura (1977). He defines it as a level of confidence in completing a given task in specific domain. In teaching, self-efficacy means the assessment of teachers' ability to teach successfully even though they must deal with less motivated students (Tschannen-Moran and Woolfolk Hoy, 1998). Furthermore, Teachers with high efficacy have the desire to achieve higher, high expectations for their students, a strategy to achieve their goals, responsible for their students, a positive outlook on teaching and they can influence their students' learning (Ashton, 1984). Teachers with high self-efficacy are important to have in schools to have successful teaching and learning.

Research suggest that the education system should improve self-efficacy of student teachers (Pendergast, Garvis, \& Keogh, 2011; Arslan \& Karamese, 2018; Wenner, 2001). Furthermore, Teachers' self-efficacy starts to grow when they start their study in university (Spector, 2004; Wenner, 2001, and Martin 1989) and it is easier to be established when are studying at university (Arslan \& Karamese, 2018). Therefore, it is very important to create an educational system or curriculum that also helps students to develop their self-efficacy. The current study aims to find out the student's self-efficacy in four different batches because if the curriculum is successfully developing the self-efficacy then the higher the student's academic year the higher their selfefficacy. There are three aspects of self-efficacy that are going to be measured, self-efficacy of classroom management, instruction, and student engagement.

The student's self-efficacy development is complex because it is linked to many factors. There are nine most influential factors to the their self-efficacy: subject matter comprehension; intrinsic motivation to be successful; working in team; computing skills; student supports and its accessibility; working on assignments issues; problem-solving skills; personal feelings on course and its materials (enjoyment, satisfaction and interest); and grades earned during their study (Hutchison, Follman, Sumpter, and Bodner, 2013). The other things that play an important role in the development of the students' self-efficacy are family supports (Turner, Chandler, \&Heffer, 2009) and mothers, professors, as well as romantic partners (Alfaro, Weimer, and Castillo, 2018). Students in different batch could encounter different factors that

${ }^{1}$ Presented in the International Conference on Creative, Teaching, Assessment and Research in the English Language hosted by Universiti Putra Malaysia on June, 26-28 2019. Part of Proceedings Books with ISBN No. 978 967-960-454-2. 
could influence their self-efficacy. This would result in different level of self-efficacy in the different academic year.

\section{MATERIALS AND METHOD}

The research object is the English education students in highly reputable private university in the field in Makassar. For confidentiality reason, we did not mention the university name. There are 122 respondents from 4 different batch, 30 students in 2015, 27 in 2016, 34 students in 2017, and 31 students in 2018)

This study employed a modified questionnaire of Teacher Sense of Efficacy Scale (Tschannen-Moran \& Woolfolk Hoy, 2001). This questionnaire was given to one class in each batch. The class was chosen randomly.

A Teachers Sense of Efficacy Scale (Tschennen-Moran \& Woolfolk Hoy, 2001) is one of the most used scales in self-efficacy. It was used to measure the pre-service and in-service teacher's sense of self-efficacy. Originally the scale consists of 24 questions but it has a short version which consists of 12 questions. The short version was used to measure English teachers' self-efficacy by Chacon (2005). In the modified scale, there are overall 12 questions. Respondents will answer the questions with 1-nothing, 3-very little, 5-some influence,7- quite a bit, and 9-a great deal. This scale was translated into Bahasa Indonesia to ensure that all participants understood the questions and responses. Translating the scale into the participant's language was important to avoid bias due to the cultural differences (King, Murray, Solomon, \& Tandon, 2004).

The reliability test result indicated that the Cronbach's alpha for overall was 0.90 . Furthermore, for the selfefficacy in engagement, instruction, and management the Cronbach's alpha was $0.81,0.86$, and 0.89 respectively (Tschennen-Moran \& Woolfolk Hoy, 2001).

All the obtained data were analysed using SPSS with independent t-test. The mean scores of all three aspects of self-efficacy then calculated in the basis of academic year. This means each construct would be divided into four groups, the students in batch 2015, 2016, 2017, and 2018. Each construct would consist of four means; means in year 2015, 2016, 2017, and 2018. The mean in each year would be computed and the result would indicate the mean score in each year. It was expected that the higher the students batch the higher their self-efficacy.

\section{RESULTS AND DISCUSSION}

The study used a nonparametric test to be specific Kruskal-Wallis because the normality test for the data was not fulfilled. The consequence of using this statistical test was that the data were compared only every two years (Tables 1-2).

Table 1. Ranks based on the intake year

\begin{tabular}{llll}
\hline & Intake Year & $\mathrm{N}$ & Mean Rank \\
\hline & 2015 & 30 & 44.87 \\
Engagement & 2016 & 27 & 52.00 \\
& 2017 & 34 & 72.38 \\
& 2018 & 31 & 73.94 \\
& Total & 122 & \\
\hline \multirow{3}{*}{ Instruction_Strategy } & 2015 & 30 & 54.62 \\
& 2016 & 27 & 50.13 \\
& 2017 & 34 & 81.94 \\
& 2018 & 31 & 55.65 \\
& Total & 122 & \\
\hline \multirow{4}{*}{ Classroom_Management } & 2015 & 30 & 48.88 \\
& 2016 & 27 & 46.17 \\
& 2017 & 34 & 83.74 \\
& 2018 & 31 & 62.68 \\
\hline
\end{tabular}


Table 2. Kruskal-Wallis test results ${ }^{\mathrm{a}, \mathrm{b}}$

\begin{tabular}{llll}
\hline & Engagement & Instruction_Strategy & Classroom_Management \\
\hline Chi-Square & 15.831 & 16.280 & 22.673 \\
df & 3 & 3 & 3 \\
Asymp. Sig. & .001 & .001 & .000 \\
\hline
\end{tabular}

a. Kruskal Wallis Test

b. Grouping Variable: Intake Year

The Kruskal-Wallis test results showed that the data distribution in self-efficacy of engagement, instructional strategy, and classroom management in the 4 year categories are significant because the values are $.001, .001, .000$ respectively. These are below 0.05 which means that Mann-Whithney can be carried out to find out whether the mean difference between one year and the year after are significant or not.

Interestingly based on the mean, it can be seen that efficacy for engagement is the only one that shows the opposite pattern, the higher the students' academic year the lower their efficacy level. The mean scores in 2015, 2016, 2017, and 2018 are 44.87, 52.00, 72.38, and 73.94. While Efficacy for instructional strategy and classroom management tend to fluctuate. Efficacy for instructional strategy shows the mean data in 2015, 2016, 2017, and 2018 are 54.62, 50.13, 81.94, and 55.65 respectively. Similar trend can also be seen in efficacy for classroom management where the mean four years are 48.88, 46.17, 83.74, and 62.68. Both data are similar. The lowest values are in 2016 and followed by 2015 . To sum up, year 2015 and 2016 are the lowest self-efficacy values compared to the other two year values (Table 3).

Table 3. Comparison between 2015 and 2016

\begin{tabular}{lllll}
\hline & Intake Year & N & Mean Rank & Sum of Ranks \\
\hline \multirow{3}{*}{ Engagement } & 2015 & 30 & 27.28 & 818.50 \\
& 2016 & 27 & 30.91 & 834.50 \\
& Total & 57 & & \\
\hline \multirow{3}{*}{ Instruction_Strategy } & 2015 & 30 & 29.97 & 899.00 \\
& 2016 & 27 & 27.93 & 754.00 \\
& Total & 57 & & \\
\hline \multirow{3}{*}{ Classroom_Management } & 2015 & 30 & 28.98 & 869.50 \\
& 2016 & 27 & 29.02 & 783.50 \\
& Total & 57 & & \\
\hline
\end{tabular}

Table 4. Mann-Whitney test results for 2015 and $2016^{\mathrm{a}}$

\begin{tabular}{llll}
\hline & Engagement & Instruction_Strategy & Classroom_Management \\
\hline Mann-Whitney U & 353.500 & 376.000 & 404.500 \\
Wilcoxon W & 818.500 & 754.000 & 869.500 \\
Z & -.830 & -.466 & -.008 \\
Asymp. Sig. (2-tailed) & .407 & .641 & .994 \\
\hline
\end{tabular}

a. Grouping Variable: Intake Year

According to the results in Table 4, in the three aspects the p-values of the Engagement, Instruction Strategy, and Classroom Management are $.407, .641, .994$. They are all greater than .05 , which means that there are 
no significant differences in the three aspects of self-efficacy in 2015 and 2016. Tables 5 and 6 show the results of comparison between the three aspects in 2016-2017.

Table 5. Comparison between 2016 and 2017

\begin{tabular}{lllll}
\hline & Intake Year & N & Mean Rank & Sum of Ranks \\
\hline \multirow{3}{*}{ Engagement } & 2016 & 27 & 24.98 & 674.50 \\
& 2017 & 34 & 35.78 & 1216.50 \\
& Total & 61 & & \\
\hline \multirow{3}{*}{ Instruction_Strategy } & 2016 & 27 & 21.94 & 592.50 \\
& 2017 & 34 & 38.19 & 1298.50 \\
& Total & 61 & & \\
\hline \multirow{3}{*}{ Classroom_Management } & 2016 & 27 & 19.63 & 530.00 \\
& 2017 & 34 & 40.03 & 1361.00 \\
& Total & 61 & & \\
\hline
\end{tabular}

Table 6. Mann-Whitney test results for 2016 and $2017^{\mathrm{a}}$

\begin{tabular}{llll}
\hline & Engagement & Instruction_Strategy & Classroom_Management \\
\hline Mann-Whitney U & 296.500 & 214.500 & 152.000 \\
Wilcoxon W & 674.500 & 592.500 & 530.000 \\
Z & -2.388 & -3.574 & -4.498 \\
Asymp. Sig. (2-tailed) & .017 & .000 & .000 \\
\hline
\end{tabular}

a. Grouping Variable: Intake Year

As shown in Table 6, the p values for all the three aspects in 2016-2017 are significantly different because the values are all below .05 .

Tables 7 and 8 show the results of comparison between the three aspects in 2017-2018.

Table 7. Comparison between 2017 and 2018

\begin{tabular}{lllll}
\hline & Intake Year & $\mathrm{N}$ & Mean Rank & Sum of Ranks \\
\hline \multirow{3}{*}{ Engagement } & 2017 & 34 & 32.29 & 1098.00 \\
& 2018 & 31 & 33.77 & 1047.00 \\
& Total & 65 & & \\
\hline \multirow{3}{*}{ Instruction_Strategy } & 2017 & 34 & 39.49 & 1342.50 \\
& 2018 & 31 & 25.89 & 802.50 \\
& Total & 65 & & \\
\hline \multirow{3}{*}{ Classroom_Management } & 2017 & 34 & 38.35 & 841.00 \\
& 2018 & 31 & 27.13 & \\
\hline
\end{tabular}


Table 8. Mann-Whitney test results for 2017 and $2018^{\text {a }}$

\begin{tabular}{llll}
\hline & Engagement & Instruction_Strategy & Classroom_Management \\
\hline Mann-Whitney U & 503.000 & 306.500 & 345.000 \\
Wilcoxon W & 1098.000 & 802.500 & 841.000 \\
Z & -.318 & -2.911 & -2.413 \\
Asymp. Sig. (2-tailed) & .750 & .004 & .016 \\
\hline
\end{tabular}

a. Grouping Variable: Intake Year

Based on the results of Table 8, the efficacy for engagement is not significant because the palue is .750 while in efficacy for instructional strategy and classroom management are significantly difference because the values are .004 and .016 .

\section{DISCUSSION}

\section{Efficacy for Engagement}

The mean scores of the students from year 4 (2015), 3(2016), 2(2017), and 1(2018) were 44.87-52.0072.38-73.94 respectively. This shows that the higher the student batches the lower their self-efficacy of engagement. This finding is alarming because the lowest self-efficacy of engagement was in the students in the year 4. This means that the higher the students' batch does not guarantee that their efficacy would be higher even though they have been learning for more years.

\section{Efficacy for Instructional Strategy}

Efficacy for Instructional strategy indicated a fluctuate trend from 2015 to 2018. The results were 54.6250.13- 81.94-55.65 respectively. The results were also interesting because year 4 was the second lowest self-efficacy for engagement and year 2016 was the lowest. They have been studying for about 4 and 3 years but their efficacy is lower compared to their juniors.

\section{Efficacy for classroom management}

Efficacy for classroom management had a fluctuate trend. It was similar to the efficacy for instructional strategy. The mean from 2015 students to 2018 students were 48.88-46.17- 83.74-62.68. The students from batch 2015 had the second lowest self-efficacy for classroom management and batch 2016 was the second low.

The result of the study was shocking because the students in the year 4 and year 3 had the lowest selfefficacy. In year 4, the student's efficacy for engagement was the lowest whereas self-efficacy for instructional strategy and classroom management were the second lowest. The lowest self-efficacy for instruction strategy and classroom management were in the year 3 and the in that year efficacy for engagement was the second lowest. It can be said that the students in the year 3 and 4 had the lowest selfefficacy level. In fact, they were about to finish their study and enter the profession which according the previous study (Weinstein, 1988) ) their efficacy would decrease because they are shock with the teaching reality.

In the year to year comparison, it can be identified that the year 2 and year 3 were the most significantly different. The students in year 2 had significantly higher self-efficacy in the three aspects that their counter parts in year 3. It is supposed to be reversed where the 3 year students should had higher self-efficacy then the 2 year student.

To sum up, educational system should ensure that the curriculum is developing the students self-efficacy as it is proposed by many experts (e.g. Pendergast, Garvis, \& Keogh, 2011; Arslan \& Karamese, 2018; Wenner, 2001). So, by the end the student's academic year their self-efficacy should be the highest so when they encounter reality shock their efficacy would not decrease significantly.

\section{CONCLUSION}

The student teachers' study time is crucial moment to develop their self-efficacy gradually. Therefore, curriculum should ensure that the students' self-efficacy of the senior students is better than their juniors. 
However, the present study indicated that the self-efficacy of the students who are about to finish their study are low compared to the students in the year 1 and 2 . Therefore, this study concludes that it is highly important to create a curriculum which ensures the student's self-efficacy development. All the teaching and learning process in earlier year should be the basis to improve the next year self-efficacy. Therefore, the higher the student's academic year the higher their self-efficacy will be.

\section{REFERENCES}

Alfaro, E. C., Weimer, A. A., \& Castillo, E. (2018). Who Helps Build Mexican-Origin Female College Students' Self-Efficacy? The Role of Important Others in Student Success. Hispanic Journal of Behavioral Sciences, 40(4), 431-447.

Arslan, A., \& Karamese, E. N. (2018). The Effects of Prospective Teacher-Lecturer: Rapport on Prospective Teachers' Attitudes and Self-Efficacy Beliefs towards Teaching Profession. International Journal of Psycho-Educational Sciences, 42 - 51-42 - 51.

Ashton, P. (1984). Teacher Efficacy: A Motivational Paradigm for Effective Teacher Education. Journal of Teacher Education, 35(5), 28-32.

Bandura, A. (1977). Self-efficacy: Toward a unifying theory of behavioral change. Psychological Review, 84(2), 191-215.

Hutchison, M. A., Follman, D. K., Sumpter, M., \& Bodner, G. M. (2006). Factors Influencing the SelfEfficacy Beliefs of First-Year Engineering Students. Journal of Engineering Education, 95(1), 39-47.

Martin, O. L. (1989). Does Teacher Efficacy Begin with Teacher Education: Implications from

Marks, D. F. (2002). The Health Psychology Reader. SAGE.

Pendergast, D., Garvis, S., \& Keogh, J. (2011). Pre-Service Student-Teacher Self-efficacy Beliefs: An Insight into the Making of Teachers. Australian Journal of Teacher Education, 36(12).

Tschannen-Moran, M., Woolfolk Hoy, A., \& Hoy, W. K. (1998). Teacher efficacy: Its meaning and measure. Review of Educational Research, 68(2), 202-248.

Tschannen-Moran, M., \& Woolfolk Hoy, A. (2001). Teacher efficacy: capturing an elusive construct. Teaching and Teacher Education, 17(7), 783-805.

Turner, E. A., Chandler, M., \& Heffer, R. W. (2009). The Influence of Parenting Styles, Achievement Motivation, and Self-Efficacy on Academic Performance in College Students. Journal of College Student Development, 50(3), 337-346.

Weinstein, C. S. (1988). Preservice teachers' expectations about the first year of teaching. Teaching and Teacher Education, 4(1), 31-40.

Wenner, G. (2001). Science and Mathematics Efficacy Beliefs Held By Practicing and Prospective Teachers: A 5-Year Perspective. Journal of Science Education and Technology, 10(2), 181-187. 